\title{
Construction Aspects in Ethiopia's Architectural Traditions: A Comparative View
}

\author{
Aspectos constructivos de las tradiciones \\ arquitectónicas de Etiopía: Una visión \\ comparada
}

\author{
Aspectos de construção nas tradições \\ arquitectónicas da Etiópia: Uma visão \\ comparativa
}

Keywords $\mid$ Palabras clave $\mid$ Pallavras chave

Comparative research, Architectural typologies, Vernacular architecture, Sub-Saharan architecture, Traditional building

Investigación comparada, Tipologías arquitectónicas, Arquitectura vernácula, Arquitectura subsahariana, Construcción tradicional

Investigação comparativa, Tipologias arquitectónicas, Arquitectura Vernacular, Arquitectura Subsaariana, Construção Tradicional

Abstract $\mid$ Resumen | Resumo

The traditional architecture of Ethiopia is manifold and spreads over a wide range of climatic zones and topographies, serving a diversity of societies. Within these contexts, the architectural traditions that have emerged show extraordinary quality and adaptability. All basic kinds of building construction can be found in diverse Ethiopian building cultures and types. In this paper, selected examples of this rich heritage, from massive stone buildings to nomadic tents, are presented and analyzed as regards their tectonic aspects and materials, and cultural interpretations are proposed. Our methodology is a comparison of building features, sizes, and spans together with materials, details, and resulting structural performance, based on documented traditional types. Comparison of building cultures that are similar even though ostensibly unrelated can highlight aspects of convergent development; alternatively, they may suggest unknown or underappreciated historical cultural exchanges and influence.

La arquitectura tradicional de Etiopía es muy variada, se extiende por amplias zonas climáticas y diferentes topografías y presta servicio a diversas sociedades. En estos distintos contextos han surgido tradiciones arquitectónicas que muestran unas extraordinarias calidad y capacidad de adaptación. En Etiopía, todos los tipos básicos de construcción pueden encontrarse en sus diversas culturas. En este artículo se presentan y analizan algunos ejemplos elegidos de este rico patrimonio, desde edificios de piedra masivos hasta tiendas de nómadas, se consideran sus aspectos tectónicos y se 
proponen interpretaciones materiales y culturales. La metodología presentada en los análisis de este documento consiste en una comparación de las características constructivas, las dimensiones y los huecos, así como de los materiales, los detalles y el funcionamiento estructural resultante a partir de la documentación y los registros de tipologías tradicionales. La comparación de culturas constructivas que son similares, aunque también ostensiblemente distintas, puede poner de relieve aspectos de desarrollo convergente; alternativamente, pueden indicar intercambios culturales e influencias históricas desconocidos o poco valorados.

A arquitectura tradicional da Etiópia é múltipla e distribui-se por uma vasta gama de zonas climáticas e diferentes topografias, servindo uma diversidade de sociedades. Dentro desses diferentes contextos, surgiram tradições arquitectónicas que exibem uma qualidade e adaptação extraordinárias. Na Etiópia, todos os tipos básicos de construção de edifícios podem ser encontrados numa diversidade de culturas. Neste artigo, é apresentada e analisada uma selecção de exemplos deste património rico - desde edifícios de pedra massivos a tendas nómadas - no que diz respeito a aspectos tectónicos, e são propostas interpretações materiais e culturais. A metodologia utilizada nas análises deste artigo é uma comparação de características, dimensões e vãos de construção, assim como materiais, detalhes e desempenho estrutural resultante, com base em documentação e registros de tipologias tradicionais. A comparação de culturas de construção que são semelhantes, embora ostensivamente não relacionadas, pode destacar aspectos de desenvolvimento evolutivo convergente; alternativamente, podem sugerir trocas e influências culturais históricas desconhecidas ou subvalorizadas.

\section{Introduction}

Architectures materialize within the constraints of geoenvironmental conditions, available resources, and social, political, spiritual, and other collective aspirations to the perpetuation of cultures, including building traditions. Research into traditional architecture provides information on the contexts and the boundary conditions that generated the "living" architectures of today. Architecture here is understood to encompass all of the built environment, including building traditions that evolved without central planning, controlled authorship, patronage, or formal training, growing out of multi-generational shared experience of "making", accruing incremental refinement and evolving into distinct material and visual cultures.

The rich heritage of architectural building traditions in Ethiopia has so far been documented only in part, and an exhaustive compilation remains to be made. Many of those traditions have been driven to the brink of extinction by rapid socioeconomic developments, and so it is timely to focus on their documentation, investigation and preservation.

From an architectural perspective, typological research is based on the documentation of specific dwellings and ensembles in order to arrive at a generic description of building types. This paper refers to broad research, and extensive documentation of many building cultures is still needed. The approach taken here is a phenomenological, qualitative comparison of building types, construction characteristics and features, referring either to exemplary single buildings documented by the authors or to referenced work by other researchers in the field.

The perspective of building construction is interesting in that it integrates the influencing factors of technical knowledge and craftsmanship, spatial relations, and available materials and resources. Building processes are usually also integrated with local customs and intangible heritage, further connecting this field with sociocultural studies. While building processes may be self-evident, detailed descriptions are scarce and beyond our scope, as are the aesthetic quality, sociocultural relevance, and adapted usage of the various types.

Comparison with international examples provides a wider context for understanding these architectures and suggests convergent as well as dissimilar aspects of evolutionary development in the types studied.

\section{Comparative analysis of construction types in Ethiopian traditional architecture}

Ethiopia is a large tropical country and due to its diverse topography and varying elevations, it includes a range of climatic subzones - arid, semi-arid, tropical, savannah, and even sub-alpine. Much of Ethiopia lies at altitudes of more than $2000 \mathrm{~m}$ and has a tropical monsoon climate, with fairly uniform mild temperatures all year. In its lower regions, in the east and south, the climate is significantly hotter and drier. This great diversity has implications in geology, vegetation, precipitation and the availability 


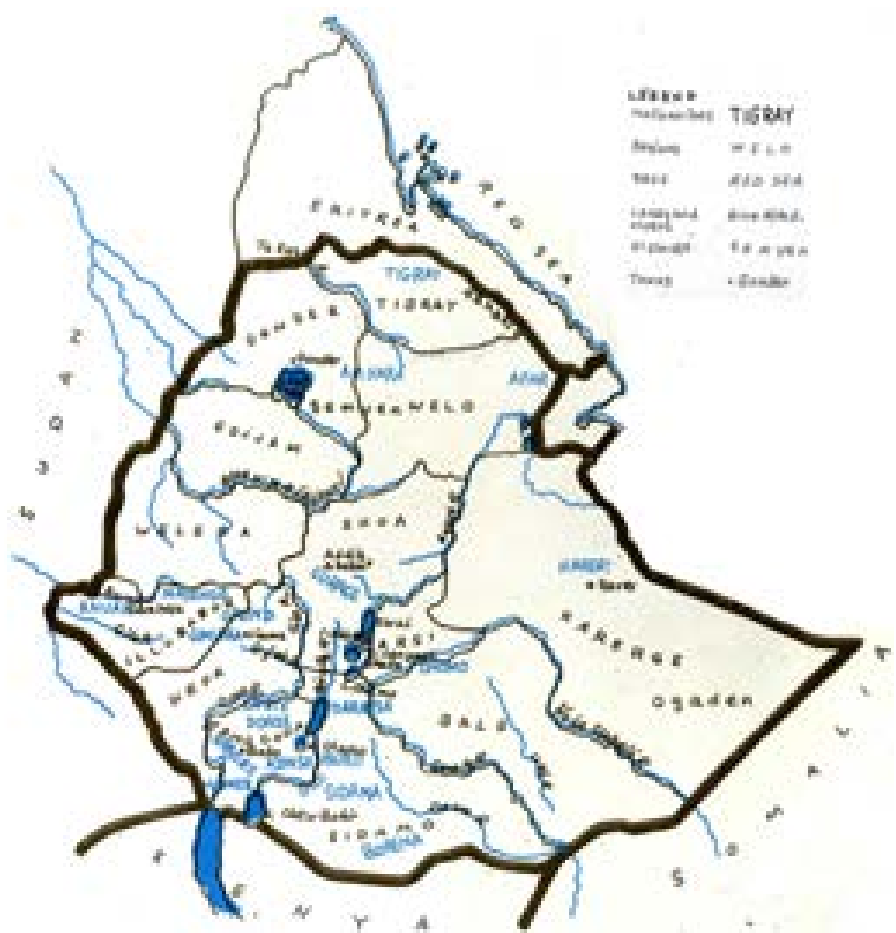

Figure 1: Map of Ethiopia with the different regions and ethnicities (Ethiopia Tourism Corporation 1981)

and performance of building materials, and thus results in a highly pluralistic ecosystem of building traditions, materials, and visual cultures.

Distinct building traditions have evolved over millennia owing to the diverse ethno-cultural identities in this large country. The construction types to be found vary greatly, ranging from lightweight nomadic one-room dwellings to massive stone and even rock-cut edifices. The Ethiopian Tourism Commission map in Figure 1 gives a broad view of the country and of its main cultural groups.

In the following sections, a selection of building cultures will be briefly presented and categorized by construction type. This overview and the types presented are by no means an exhaustive description of Ethiopian traditional

Figure 2: Afar home, so-called Deboita, around Logya area (Alice Eigner 2011)

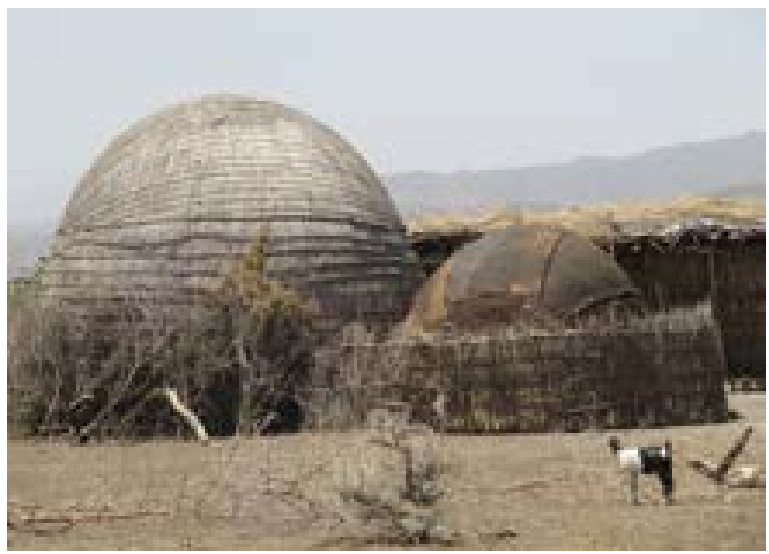

architecture, but they give an insight into the great variety of building cultures present. The selection includes types experienced by the authors, students, and colleagues that are in some ways unique, as well as others that are comparable with traditions found in neighboring countries or whose characteristics evoke building traditions in other parts of the world.

The analyzed types with the corresponding communities and locations are:

1. Lightweight nomadic structures: Afar, Mursi and Dassanech.

2. Lightweight fixed and woven structures: Dorze and Sidama.

3. Timber structures: Konso/Xonsita.

4. Massive stone structures: Tigrinya.

5. Hybrid building with timber and adobe: Chikka construction in the Oromia region.

6. Hybrid building with timber and stone: Axumite construction in the Tigray region.

7. Cave structures: Churches primarily in the Tigray region.

\section{Lightweight nomadic structures: The Afar and Mursi}

\subsection{The Afar}

The Afar are a nomadic people living in northeast Ethiopia in the border region of the Danakil desert between Eritrea and Somalia, in a hot and arid environment. They have a pastoralist lifestyle, so their villages are temporary settlements along cattle routes. Thus livestock enclosures and houses are cyclically abandoned and reused upon return.

Figure 3: Grid shell made of sticks bound together founded in the ground (Alice Eigner 2011)

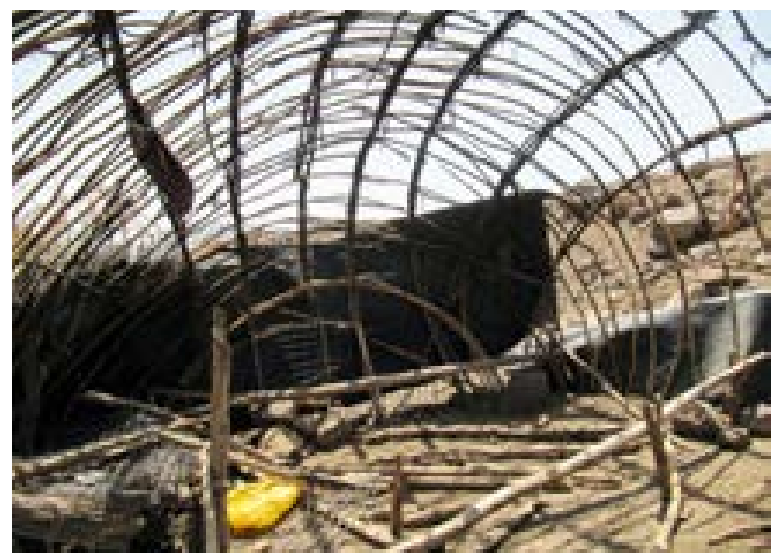



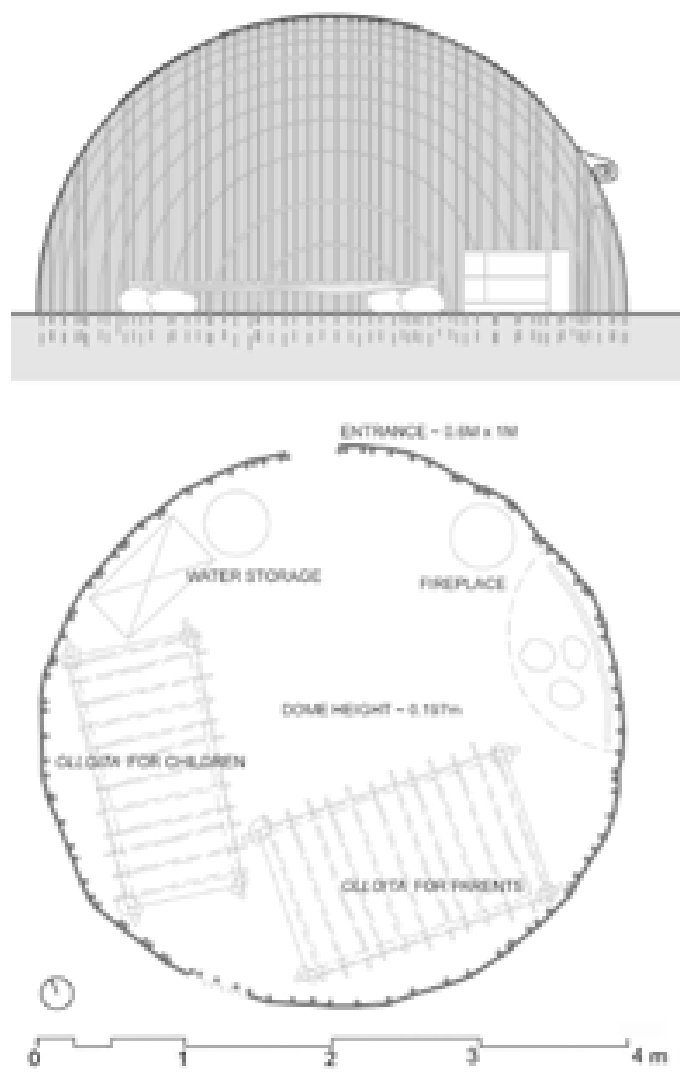

Figure 4: Plan and section of typical construction of an Afar Deboita house (Emilia Chocian 2012)

Their usual dwellings are portable dome tents with a single space for both sleeping and cooking called deboita. This has a simple yet elaborate and expansive domed structure with a framework of sticks bent and wound together with strips of dried animal skin and covered with woven mats of palm leaves, and nowadays also with plastic and tarpaulin (Figs. 2,3 and 4). The height of deboitas varies but is rarely greater than $2 \mathrm{~m}$. The adjacent house is sometimes connected with a small annex entrance. All components of deboitas are carefully made to be disassembled and packed onto handmade saddles on camels and donkeys (Fig. 5).

\subsection{The Mursi and Dassanech}

The Omo is one of Ethiopia's largest rivers and its lower valley with its many ethnicities is undergoing change with development, shifts in land use, tourism, and government resettlement efforts. Living along the Omo and its tributary the Mago, in southern Ethiopia near Kenya, the Mursi are a nomadic agro-pastoralist people mostly known for their elaborate body decorations with paint, plants and other materials, and their womenfolk's ceramic lip plates. Though theirs is a hot and semi-arid mountain environment, Mursi dwellings are similar to Afar ones, only less refined and detailed as they are not transported. The Mursi use sticks arranged centrally and covered with grass thatch (Figs. 6 and 7). Other tribes in southern Ethiopia, for example the semi-nomadic Dassanech, also live in domed dwellings.
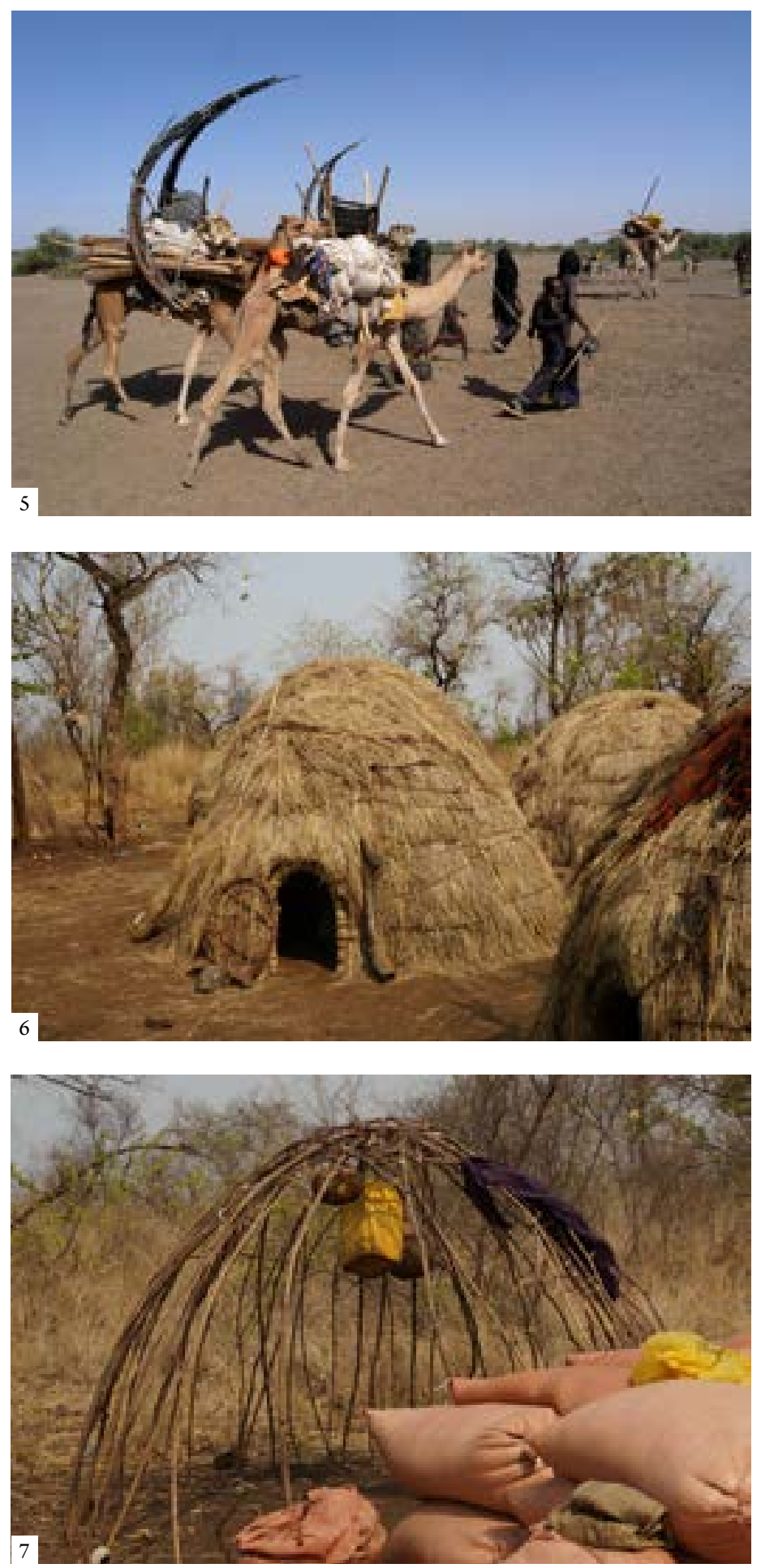

Figure 5: Afar group moving with camels and donkeys carrying the entirety of the household

Figure 6: Mursi house in the Omo Valley in South Ethiopia

Figure 7: Structural grid made of radially arranged branches bent and tied at the apex

Their villages are located along the Omo river and the north shore of lake Turkana in Kenya and can consist of 5 to 30 houses, built by women for their nuclear families. Nowadays, besides plant material, they also use tarpaulin, plastic sheeting, and sheet metal as thatch (Figs. 8 and 9). 


\subsection{Comparison with the Hadza in Tanzania}

The Hadza are a small tribe of hunter-gatherers living in central northern Tanzania around Lake Eyasi in the central Rift Valley and on the neighboring Serengeti plateau. They are one of the last remaining such tribes worldwide and have inhabited the area for centuries. Their houses consist of domed structures built with sticks, tree bark and living plants, covered with grass and other plant material. The structures are makeshift but allow amply for sleeping and cooking. A variation of this dwelling has twin domes with a connecting entrance (Figs. 10 and 11). A feature unique to the Hadza shelter is the integration of living plants in the primary structure as a support for the sticks forming the dome framework (Fig. 12).

Domed dwellings are a frequent building type of nomadic people and can be found in many parts of sub-Saharan Africa. They are usually made with locally available plant material and the structure height is limited to some $2 \mathrm{~m}$. Most dwellings are too small for standing upright inside. Portable structures such as the Afar dwellings are more elaborate and elements such as building sticks and covering woven mats are carefully selected and crafted.
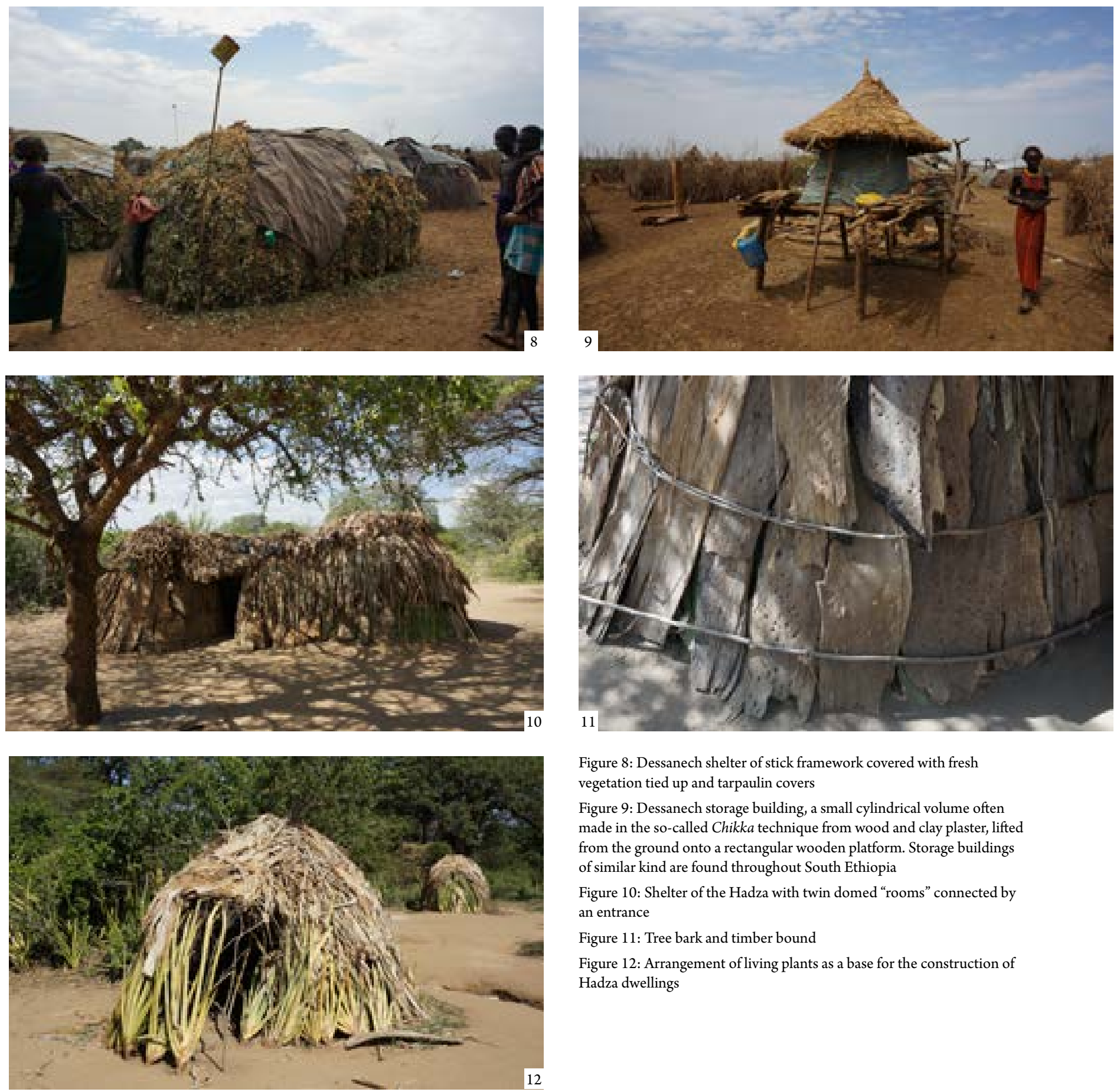

Figure 8: Dessanech shelter of stick framework covered with fresh vegetation tied up and tarpaulin covers

Figure 9: Dessanech storage building, a small cylindrical volume often made in the so-called Chikka technique from wood and clay plaster, lifted from the ground onto a rectangular wooden platform. Storage buildings of similar kind are found throughout South Ethiopia

Figure 10: Shelter of the Hadza with twin domed "rooms" connected by an entrance

Figure 11: Tree bark and timber bound

Figure 12: Arrangement of living plants as a base for the construction of Hadza dwellings 


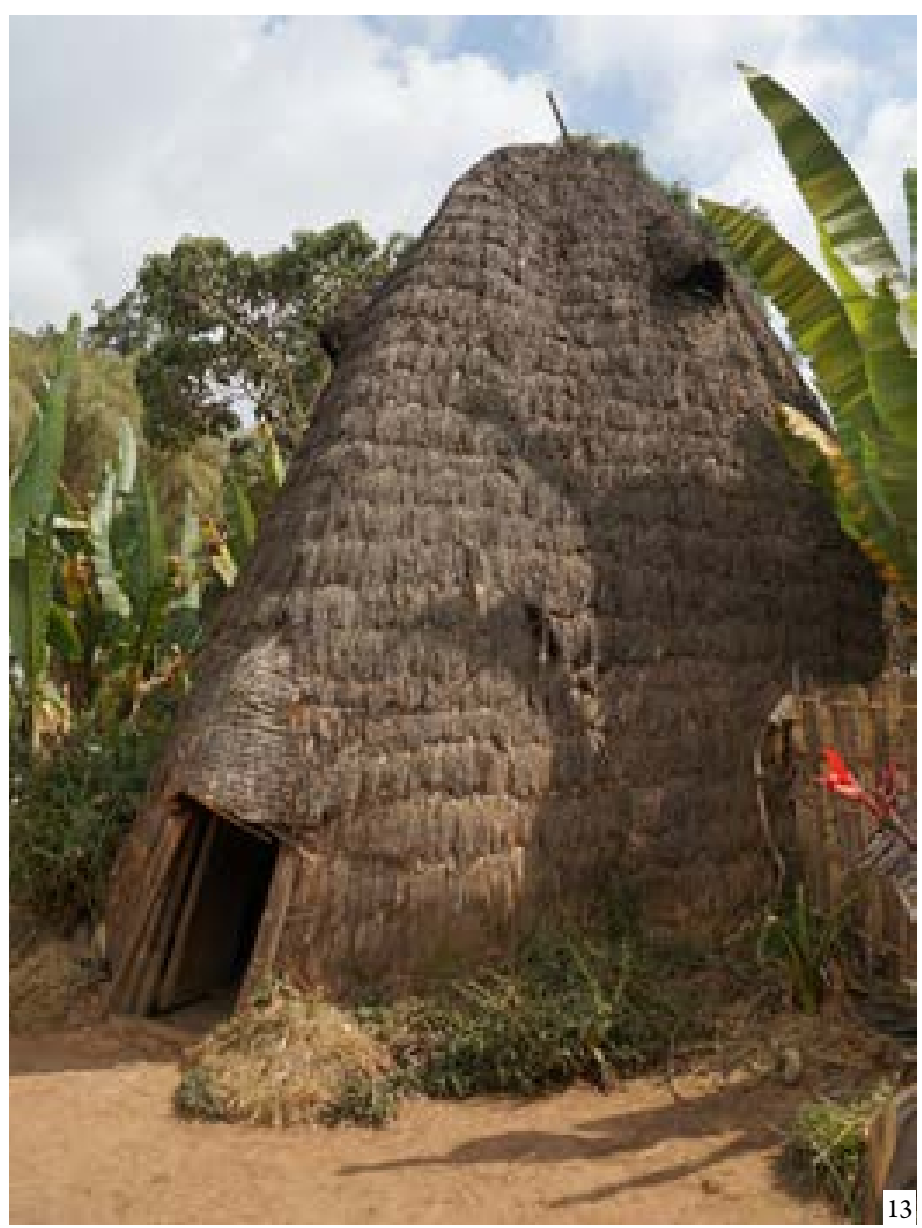

Figure 13: Dorze house made of bamboo around Arba Minch area Figure 14: Dorze house under construction with horizontal sticks as a temporary scaffold for access

Figure 15: Interior of the house under construction

Figure 16: Few rigid elements like the door frame of bundled split bamboo

Figure 17: Traditional house in Luang Prabang, Laos, made of a timber primary structure and woven bamboo walls

\section{$\underline{2 \text { Lightweight, tied and woven structures: Dorze and }}$ Sidama}

\subsection{The Dorze}

The Dorze are a small sedentary ethnic group living in the Arba Minch area of southern Ethiopia. Their architecture is built almost entirely with split bamboo and has a distinct characteristic format (Fig. 13). The diameter and height of these structures easily attain $8 \mathrm{~m}$. The Dorze are renowned for their weaving craftsmanship, shown even in their dwellings, resembling round woven baskets. The vertical bamboo sticks are simply embedded in the ground, and the elaborate weaving pattern is designed for a peaked dome shape. An equally organically shaped entrance annex is attached to the main dome (Figs. 14 and 15). The thatch is made of plant leaves and can be repaired and renewed. The interior of large houses is subdivided by woven bamboo walls (Fig. 14). The details of openings are crafted with rigid bundles of bamboo (Fig. 16).
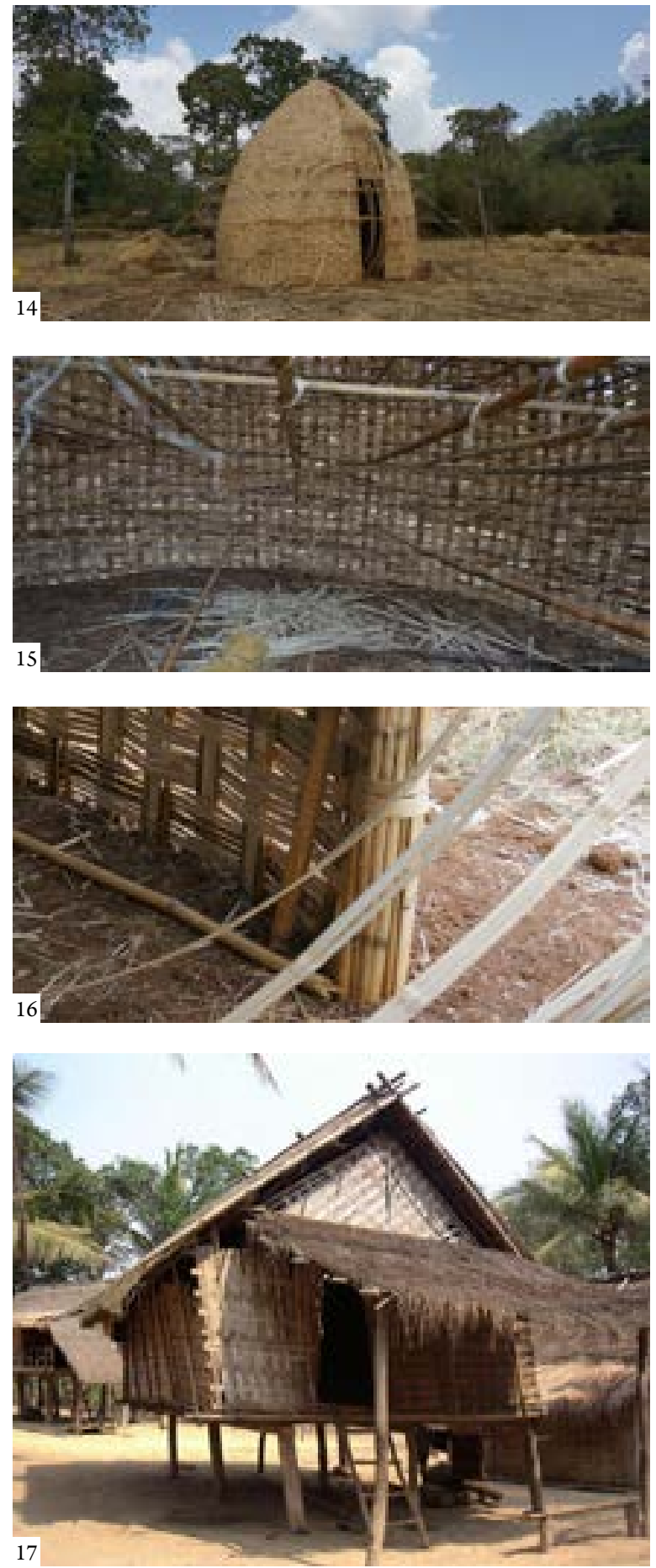

\subsection{The Sidama}

In comparison, the houses of the Sidama people in a nearby region have a similar structure type with a different, onionshaped dome held up internally by a timber pillar. Woven bamboo houses form a unique construction typology worldwide. The material is very sustainable, as bamboo is a fast-growing plant that thrives in many climates. Especially in the tropics, bamboo is most commonly deployed in construction in woven mats forming walls, such as for example in Thailand and Laos (Fig. 17). 
3 Timber construction: Konso community in the eponymous World Heritage region

\subsection{The Konso}

The UNESCO World Heritage Konso Cultural Landscape in the south-west highlands of Ethiopia is an arid region of settlements fortified with stone-walled terraces. The Konso architecture is noteworthy in that it represents a rare example of an indigenous fortified settlement paired with unique wooden building types. The villages consist of dry-stone terraces with timber buildings, thus requiring both stone and timber craftsmanship (Fig. 18). The intrinsic relationship between architectural features and sociocultural norms is observable in the spatial differentiation of open areas, containing a network of pathways between private compounds and gathering places, with wooden stelae representing ancestors. The architecture features a range of building types, with spatial layouts and construction methods suited to their function and usage (Weldekian 2015). Notable among these are the storage and assembly buildings spread about the villages.

Figure 18: A fortified village in the Konso region on top of a hill with concentric terraced arrangement and adjacent agricultural land

Figure 19: Paffta house with two-tiered open plan and storage under one roof

Figure 20: Doubling of construction element in the center with the central pillar of the platform and the central pillar of the roof

Figure 21: The space under the roof is used by the community men for meeting (Garedew M. Weldekian)

Figure 22: Plans at ground level and first floor level, elevation and section of a typical Paffta type communal house (Garedew M. Weldekian)
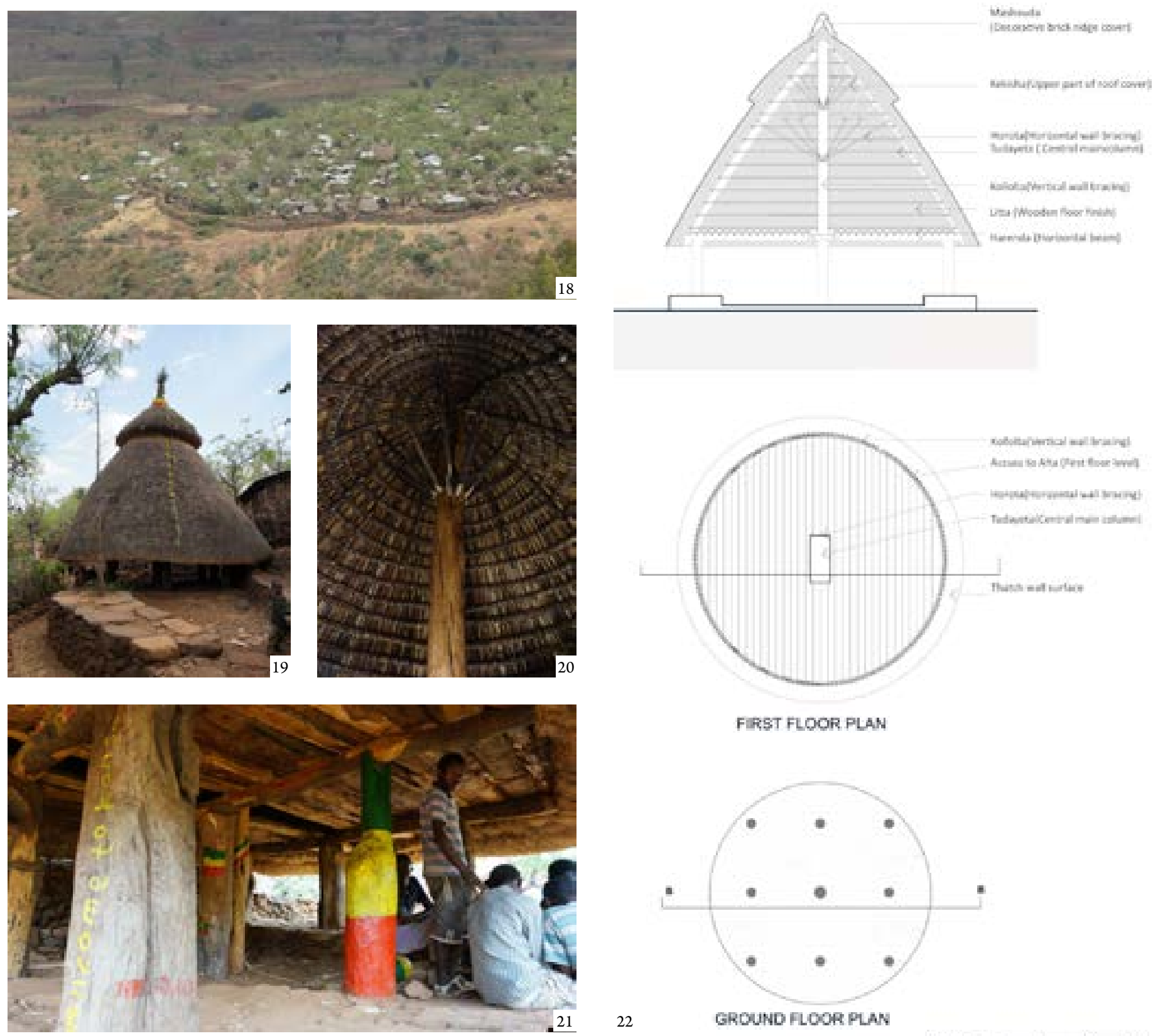

FIRST FLOOR PLAN
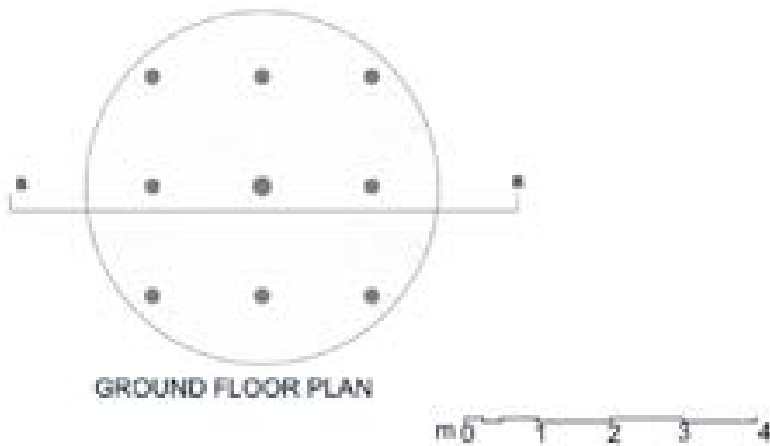
In the Konso region, the paffta is a communal house consisting of a raised stone base, a timber platform on pillars and a large roof space supported by a central pillar. The space under the platform is not high enough for standing upright but allows for comfortable sitting on the stone base (Figs. 19 and 20). The roof space is accessible and used for storage. The construction elements for the platform and the central pillar of the roof are theoretically aligned, as can be seen in plans and images (Figs. 21 and 22).

\subsection{Comparative analysis with Sulawesi and Sumatran communities}

Different building traditions in Southeast Asia, such as the architecture of the Toba Batak in Sumatra and the Toraja in Sulawesi, both large islands in the Indonesian archipelago, feature similar building types and similar methods for food storage and meeting spaces. These buildings have different roof shapes but apply the same concept of vertical functional differentiation. In western Indonesia, a variation of the corresponding dwelling is a storehouse called Sopo (Fig. 23). In the case of Toba Batak communities in Sumatra, dwellings face storehouses along the main axes of villages.

Figure 23: Traditional Toba Batak Sopo on Samosir island, Sumatra, Indonesia, a building type for rice storage with a raised platform used for congregation (Erich Lehner)

Figure 24: Longitudinal Section through a typical Toba Batak Sopo structure (Gaudenz Domenig, Tektonik im Primitiven Dachbau: 149)
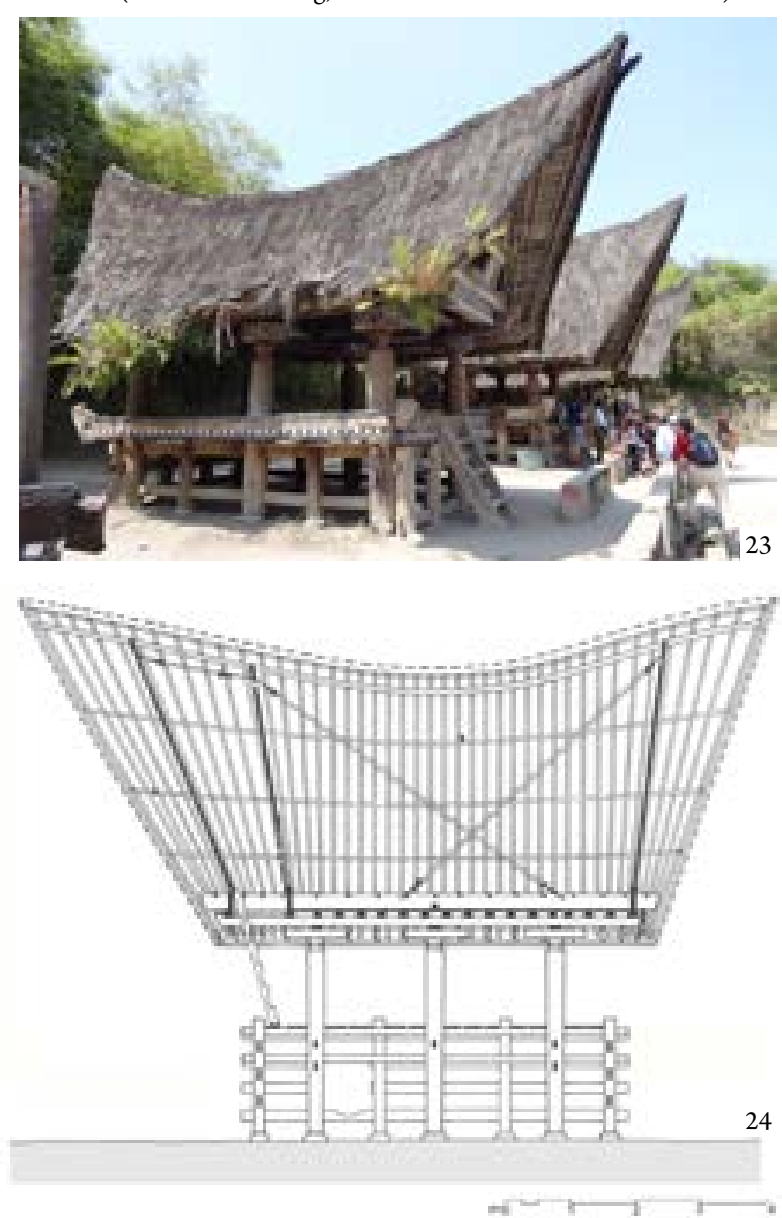

Specific construction aspects of traditional architecture in Indonesia are described by various researchers (Schefold et al. 2004) and include the combined characteristic roof assembly and platform structure. In many building traditions, both structure types are present and spatially overlap in the substructure below or even in the living area. The main difference between the Toba Batak and the Konso traditions is in the raised timber platforms and the extent of refinement in woodwork and orientation. Covered platforms for shelter and meeting are a common type across the world, but the parallels between Indonesian and Konso architecture in function and structure are striking. Information is lacking on the historical development of these types but considering the geographical distance, they are assumed to have evolved separately in convergence, based on similar agricultural lifestyles, similar sociocultural organizational structures, and similar climate and availability of resources.

\section{Massive stone and hybrid structures: Tigray region}

\subsection{The Tigrinya}

The built environment of northern Ethiopia is characterized by rural farmhouse types integrated into an agricultural landscape. The prevailing building material is stone, and due to the arid climate, timber is scarce and valuable. So the use of timber is restricted to that needed for roof structures, lintels and doors. These flat-roof buildings and settlements blend entirely into the landscape. (Fig. 25) The homesteads consist mostly of two distinct buildings arranged around a courtyard enclosed by a stone wall, with stables and shelters for livestock. The traditional farmhouse called hidmo shares structural features with the famous traditional rock churches of the Gheralta mountains (Nobuhiro 2015). The walls consist of dry-stone masonry plastered inside with earthen render. Collapsed buildings reveal a dual-wall technique providing an inner and outer shell, with an unsmoothed stone surface and filling inside. The few openings are made with timber lintels and are often ornamentally framed with white lime paint (Fig. 26). The roof structures are hierarchically layered so that the main pillars and beams are probably the only elements needing to be brought from other regions, where timber in such dimensions still grows.

It is worth noting that in simple rectangular houses the main beam follows the longer middle axis, and is therefore supported by one or two pillars (Fig. 27). With this primary structure, the secondary beams need to span only half the room width and can therefore be sourced locally from the eucalyptus that is cultivated by many farmers. The filling between the beams can consist of branch materials. In more elaborate timber structures, branches are laid in a diagonal arrangement. The timber structure is then covered with layers of soil and gravel. The transition between wall and roof bears a conspicuous detail: just above the secondary beams of the roof structure, overlapping stone slabs 
are laid in such a way as to project from the wall surface, thus forming a continuous linear cornice surrounding the building (Figs. 28 and 29). These layers of stone slabs double up as rainwater protection and sun shading for the walls and, by extension, for their built-in timbers. In many cases, plant material has been seen to be used to additionally cover the roof surface, or plants are grown on the flat roofs.

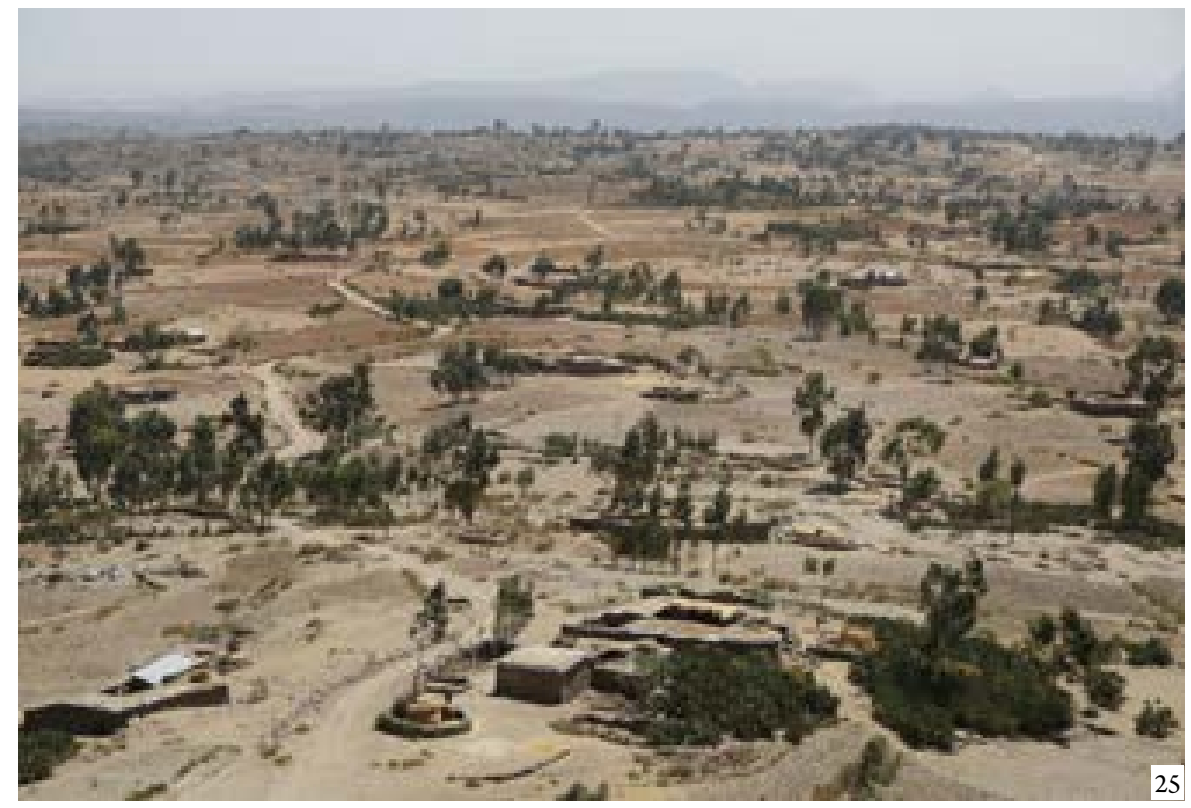

4.2 Comparative analysis with communities in the Asir region of Arabia

Despite their simplicity, the structures and details of the building traditions in the Tigray region are akin to those found in Saudi Arabia, especially in the southern Asir region, bordering with Yemen. The farmhouses there are also dispersed over terraced farming landscapes. They have a dual use as both living and working spaces but
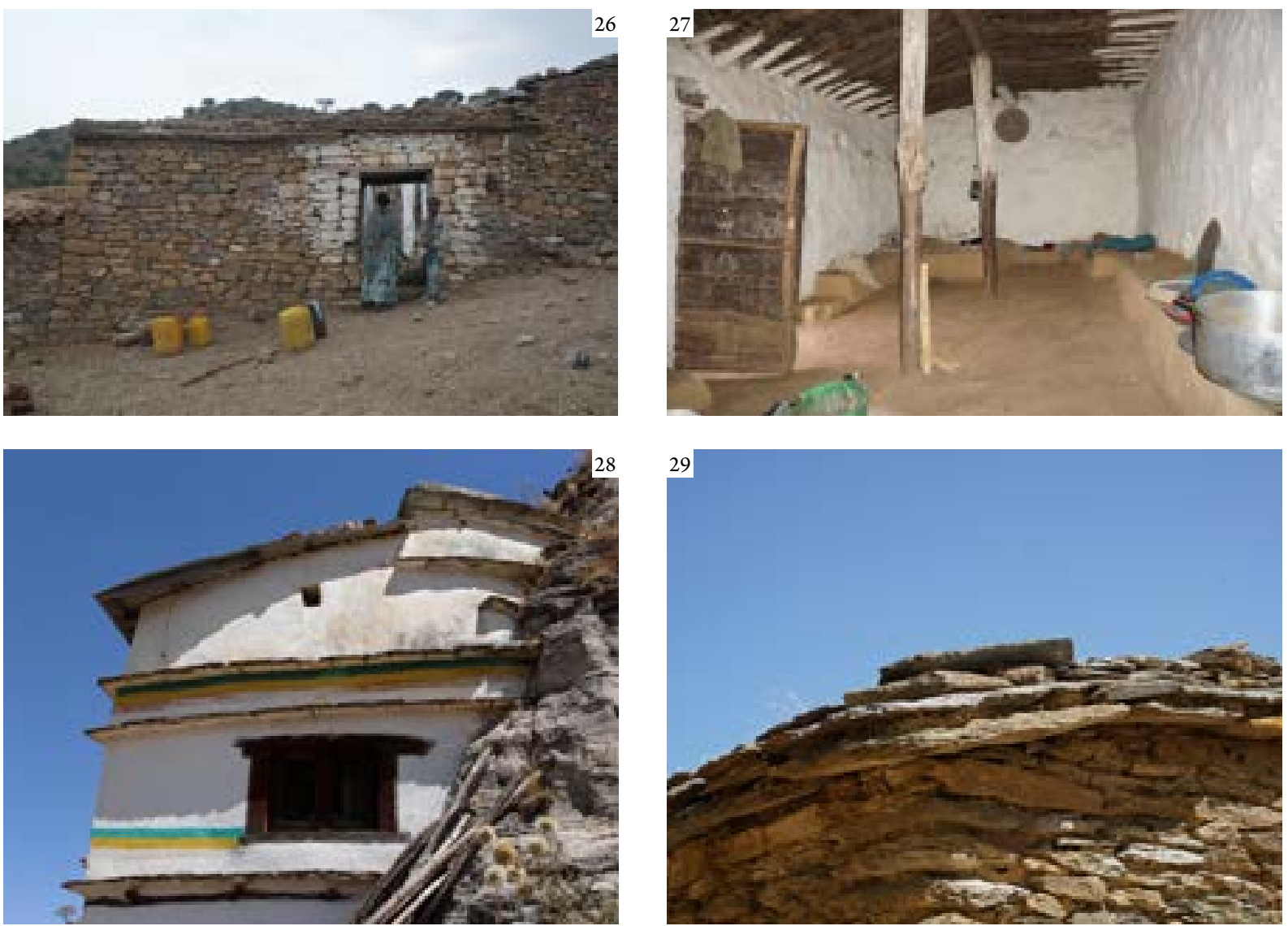
are much larger in scale, covering a few hundred square meters and up to three floors. These homesteads are also clustered in ensembles and enclosed within dry-stone walls (Sieghartsleitner 2010) (Fig. 30).

Buildings are constructed in locally available materials: stone, loam and timber. Wall structures are vertically differentiated into dry-stone walls for ground floors called zabur, and mikmak in upper floors. This is wet-loam
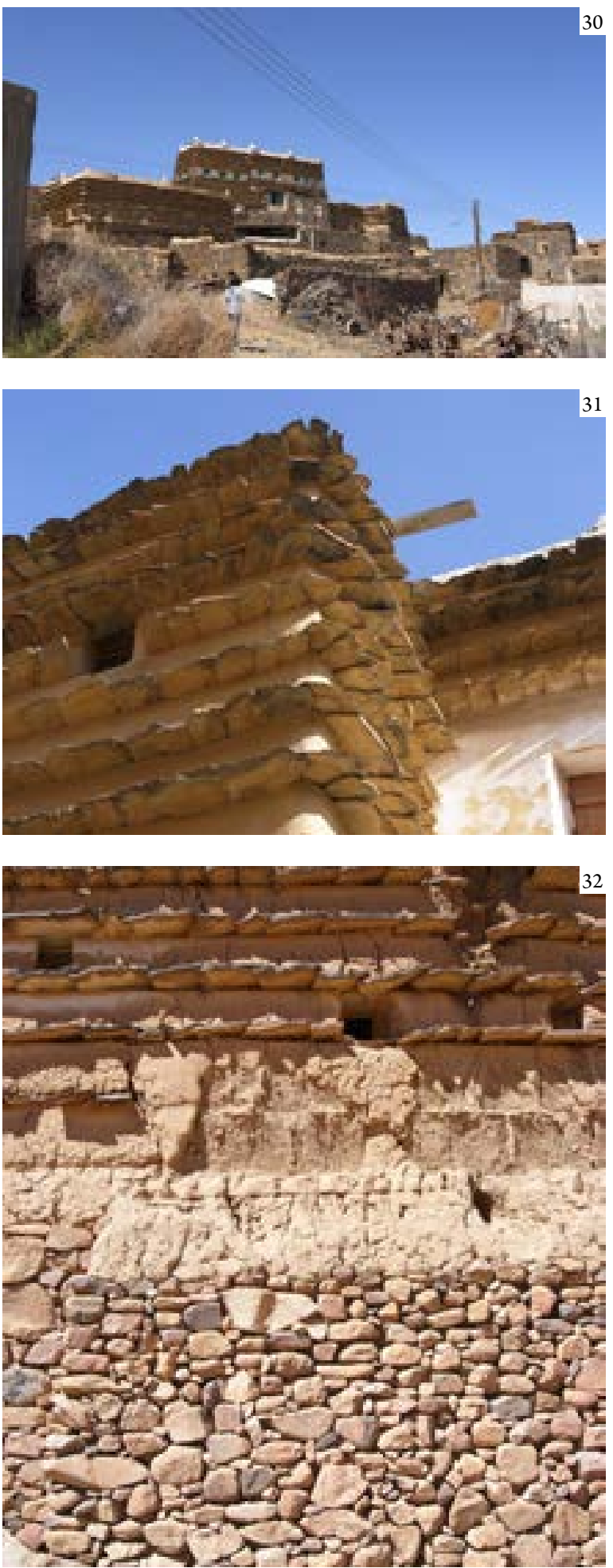

building with layers of $50-80 \mathrm{~cm}$ needing no formwork, molds or specific tools - a widespread method of traditional construction in Africa. Specific to the buildings found in the Asir region are the courses of flat stones marking the construction layers. Farmhouse facades are thus typically structured horizontally, with small wall openings interrupting the pattern (Figs. 31 and 32). As in Tigray, the margins of openings are painted. Another typical feature of Asir architecture is roof protrusions. The earthen wall structure is protected from rain and the ground-floor stone walling prevents damp from reaching the earthen parts. As the wall thickness becomes thinner in the upper floors, the

Figure 30: Traditional farmhouse ensemble in the Asir region of Saudi Arabia

Figure 31: Facade detail with rows of slightly overlapping flat stone slabs as rain protection

Figure 32: Facade detail with dry stone wall on ground floor and Zabur adobe building technique with rows of flat stone slabs on the upper floors. Figure 33: Plan of the ground floor and section through the entrance courtyard of a typical Asir house measured on-site (Alexander Sieghartsleitner 2010)

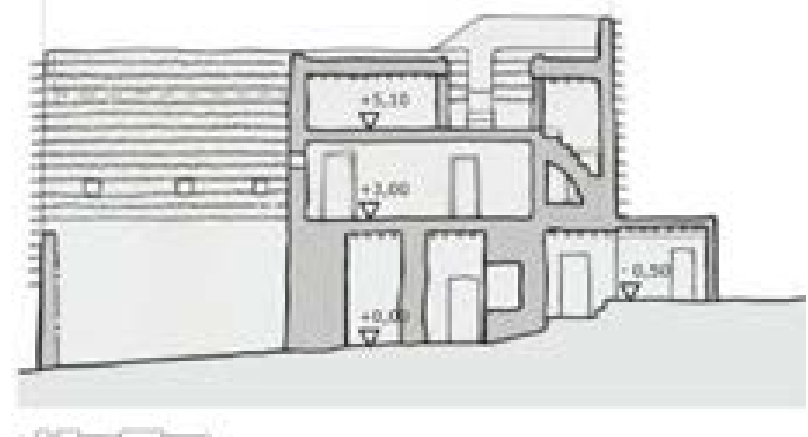

$+b^{4}+\sqrt{-1+2}$

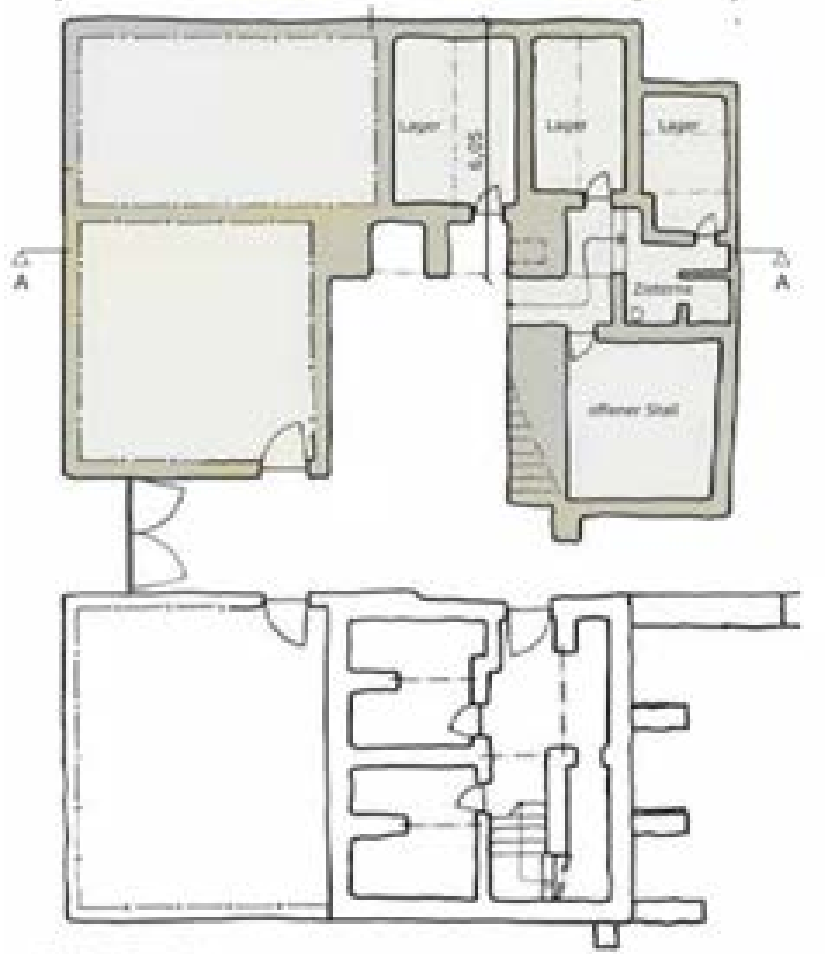


walls look inclined, giving the buildings their characteristic trapezoidal appearance (Fig. 32). This can also be observed from scale drawings of a typical Asir house (Fig. 33).

Such earthen construction is not common in Ethiopia, but the use of earth in plaster mixes, called the chikka technique, is widespread. The features common to the building traditions of Saudi Arabia and of northern Ethiopia can be attributed to a centuries-long diffusion process in the Red Sea area (Breton 2015). The currently closed borders and difficult political situation in the region are alien to such traditional exchanges.

\section{Hybrid structures: Axumite construction}

\subsection{Axum}

Axumite architecture dates back centuries and can today be studied in just a few churches in northern Ethiopia, Debre Damo being the most famous and reportedly the oldest, from the 6th century (Fig. 34, Friedlander, 2015). Axumite construction is characterized by alternating layers of stone masonry and horizontal timber, with crossbeams protruding and framing wall openings with characteristic "monkey heads" (Figs. 35 and 36). In the hilly areas of Debre Damo, the crossbeams are arranged systematically, resulting in an additional pattern on facades. The stoneslab layer, creating a horizontal cornice on the facade, is also present here. A more pronounced example is the Yemrehana Kristos church in the Lalibela area, from the mid-12th century (Friedlander 2015), located in a cave under a large rock overhang. The church and the adjacent buildings are built in the Axumite tradition, in masonry with timber beams carefully laid and connected at the ends. The ratio between masonry and timber is roughly $1: 3$, with beams about $15 \mathrm{~cm}$ high and plastered masonry parts slightly protruding, suggesting an initially unplastered stone facing. From a structural perspective, the crossbeams with "monkey heads" are connected to the horizontal beams and thereby not only facilitate wall openings but also add to the stability of the thick stone walls by holding the inner and outer shells together. The masonry between the beams is made of small horizontally arranged flat stones, laid with mortar and plaster. The fact that large parts of the closed side walls lack timber beams suggests a primary function as load-dispersing elements for wall openings, and in the case of Yemrehana Kristos perhaps also decorative purposes (Figs. 37 to 41 ).

Figure 34: 6th century Enda Abuna Argawi church (also, Za-Mika'el 'Aragawi) within the Debre Damo monastery in Tigray. Classical Axumite construction with horizontal wool layers and protruding cross beams (Luel Yitbarek)

Figure 35: Reconstruction of typical Axumite stone masonry with horizontal timber layers and protruding cross beams, called "monkey heads" (Hans Helfritz 1972)

Figure 36: Elevation of Enda Abuna Argawi church (Hans Helfritz 1972)

Figure 37: Yemrehana Kristos church in the Lalibela region, mid-12th century, with classical features of Axumite architecture: horizontal layering of masonry and wood, rows of windows and edge parts of the building projecting out
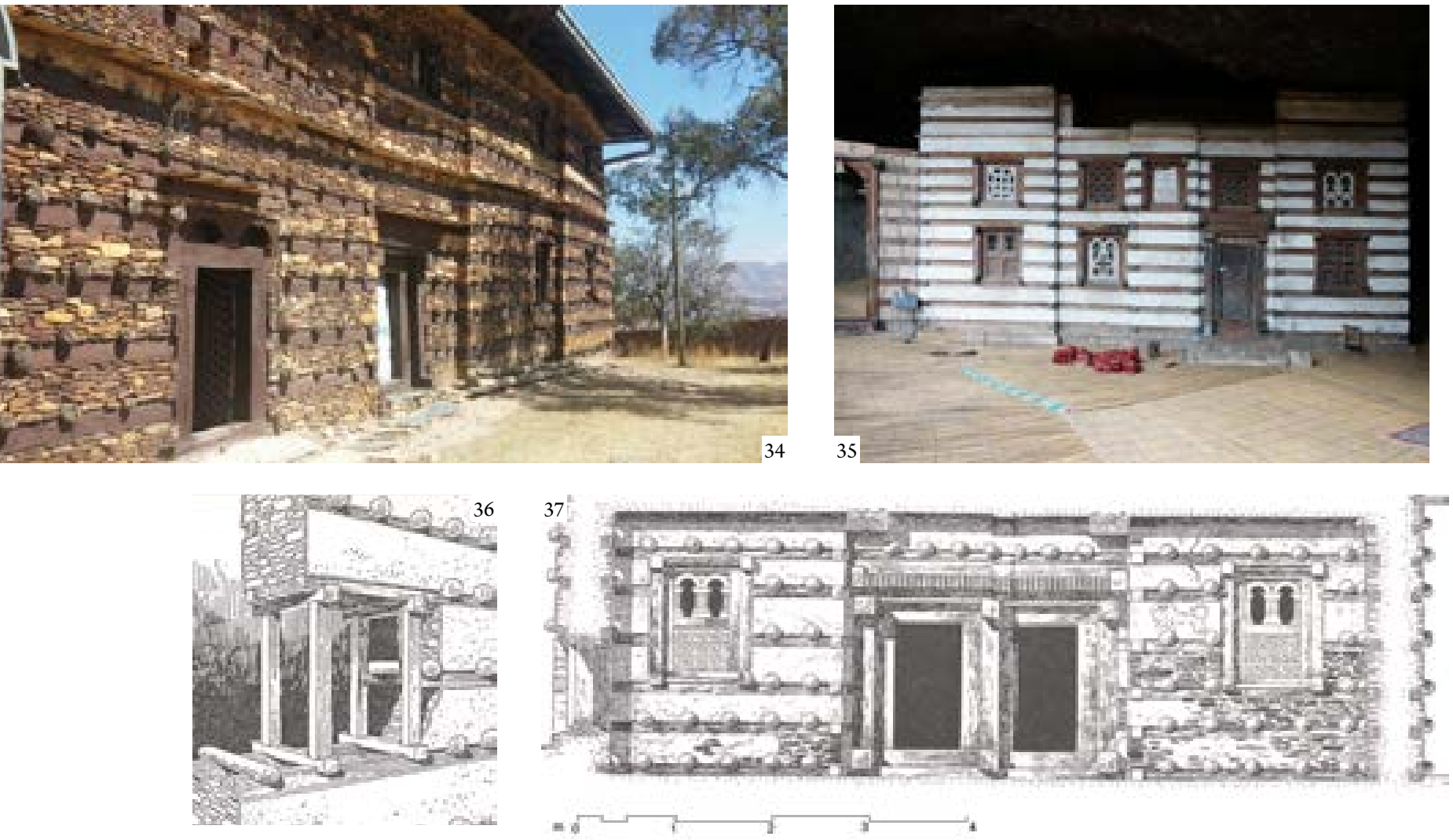

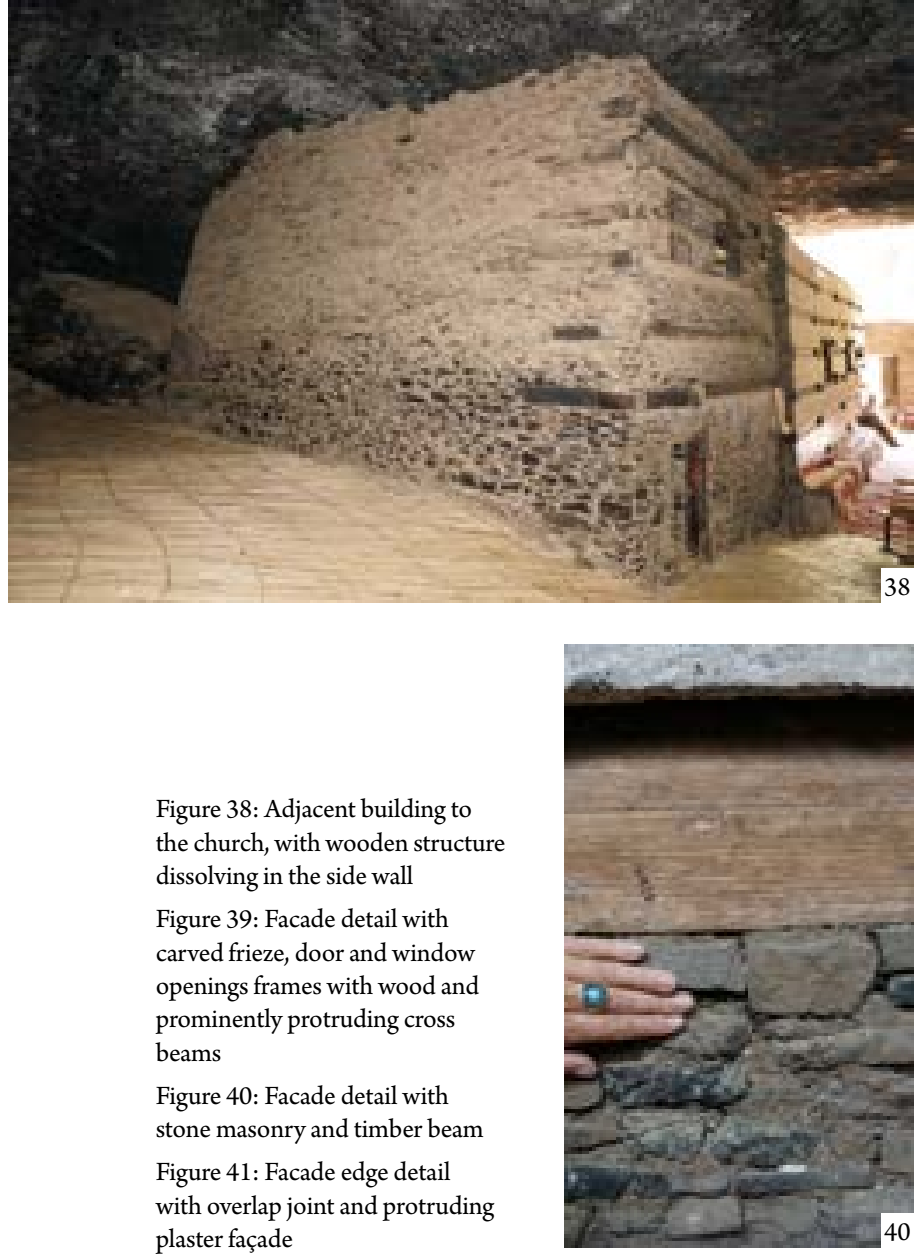

Figure 38: Adjacent building to the church, with wooden structure dissolving in the side wall

Figure 39: Facade detail with carved frieze, door and window openings frames with wood and prominently protruding cross beams

Figure 40: Facade detail with stone masonry and timber beam Figure 41: Facade edge detail with overlap joint and protruding plaster façade

\subsection{Comparative analysis with communities in the Hejaz} region of Arabia

In contrast to the uniqueness of Axumite construction, this use of masonry with alternating timber layers is widespread in the traditional architecture of Saudi Arabia, especially in the Hejaz region along the Red Sea coast. The old town of Jeddah, the trading port and entrance to Mecca, was built entirely of coral limestone and timber. Historically, Al-Balad, in Jeddah still has wonderful examples of intricately built multistoried merchant houses (Fig. 42). Locally sourced and dressed coral stone is used for building high loadbearing walls and foundations, interspersed with timber for structural support in horizontal layers, roofing, windows, doors, and the famous roshan and mashrabiya (Figs. 43 and 44). Several authors have described the traditional Jeddah building technology, and the example presented here was extensively documented in the Trabasa project (Gruber and Eissa 2014). The Al-Nawar house represents classical building construction with mainly coral-stone masonry, used in large blocks and reinforced with horizontal timber beams at distances of 80 to $120 \mathrm{~cm}$, depending on the location of wall openings (Fig. 45). The ground-floor plan and section through the courtyard show the spatial hierarchies of typical Hejaz architecture (Fig. 46).
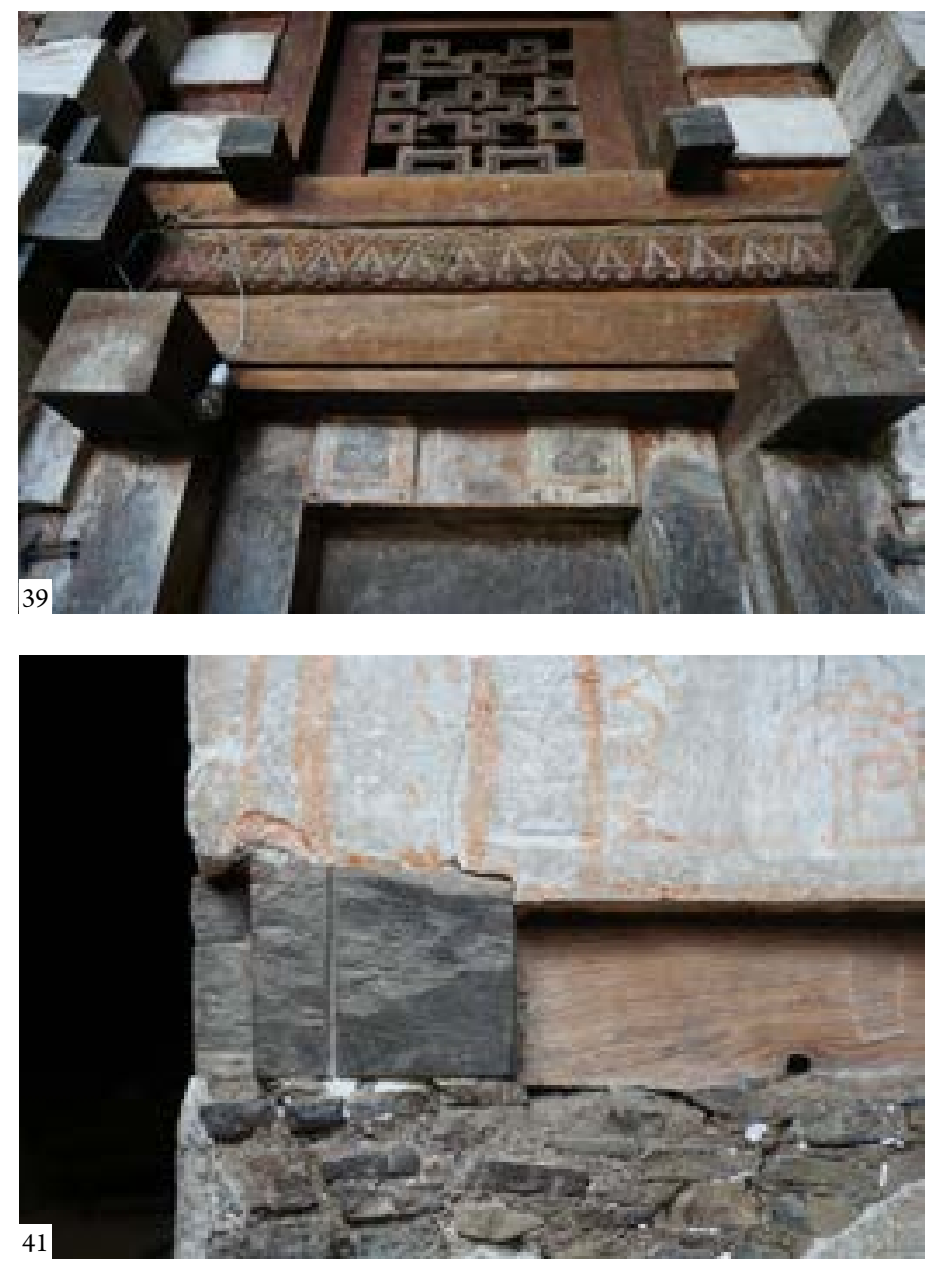

The timber layers enable load distribution within walls and provide a grid for design flexibility in fenestration allowing visual porosity and privacy while inhibiting thermal exchange. One conservation issue for this unique built heritage is the disintegration of coral stone and timber over time. The integration of contemporary building materials together with water and electricity supply due to rapid but haphazard modernization also presents challenges to these heritage settings (Fig. 47).

On comparing the architecture of old Jeddah with the Axumite building tradition, we notice the following: the same building principle is applied - horizontal layering of masonry and timber, with timber as reinforcement. Lengths and widths of walls are reinforced with overlapped connecting joints. The horizontal layering accommodates wall openings. But protruding crossbeams (monkey heads) are a distinct feature of Axumite construction. Construction is on very different scales and with different materials. In the Axumite tradition, small-scale dry masonry is used, and the ratio between masonry and timber is about $3: 1$. In Jeddah, the stones are cut, and brick masonry is used with mortar. The distance between timber layers is roughly 50$80 \mathrm{~cm}$, and the architecture in Jeddah is multistoried. 
As the Red Sea region has had centuries of cultural exchange, it is not surprising to find similarities in building construction. Horizontal layering is a specific construction type not widely encountered. Together with other similarities in Saudi Arabian and Tigrinya architecture, this construction principle is assumed to have spread through a diffusion process. Archaeological research on vernacular architecture is required to test this assumption and could tell us about the direction of information flow.

\section{Conclusion}

As stated above, an exhaustive discussion of the abundant building typology present in Ethiopia exceeds the scope of one paper. The most common types, such as hybrid construction with timber and earth or the chikka technique, are still used in vernacular praxis throughout the country, though such continuing traditional building types in the Ethiopian highlands are also beyond our scope.

From our analysis we may conclude that:

There are unique construction types and elements, such as horizontal timber layers embedded within masonry and stone slabs used for cornices, that suggest diffusion processes around the Red Sea cultural area. But for some construction types, such as the woven bamboo structures of the Dorze community in the Chencha region, no comparative architectural models have been found worldwide.

A comparative analysis with the vernacular architecture of other world regions shows that construction types in Ethiopia seem to reflect the scarcity of resources, have slightly coarser craftsmanship, and tend to use less elaborate ornamentation.

Analysis of traditional Ethiopian architectural typology has relevance beyond its specific place and time in view of these types' inherent adaptiveness, aesthetic quality, sociocultural integration, and sustainable material use. Moreover, an interesting example of a recent translation of traditional construction methods can be found at the ZOMA museum in Addis Ababa (Assegued and Sime 2002).

Extensive documentation of Ethiopian architectural types should ideally follow after overarching comparative studies such as ours, and archaeological research is needed to trace the various diffusion processes.

\section{Acknowledgments}

Acknowledgements go to all individuals, colleagues and institutions whose work was presented and cited in this paper, especially: Garedew Mengesha Weldekian, Emilia Chocian, Alice Eigner, Alexander Sieghartsleiter, Erich Lehner and the Trabasa team. Acknowledgements are also extended to the following institutions for their gracious financing \& support to the research mentioned: Vienna University of Technology, Austria, King AbulAziz University, Jeddah, Saudi-Arabia, and Ethiopian Institute of Architecture, Building Construction and City Development (EiABC), Addis Ababa University, Ethiopia.
Figure 47: Destroyed building in the old town of Jeddah, which shows the building construction

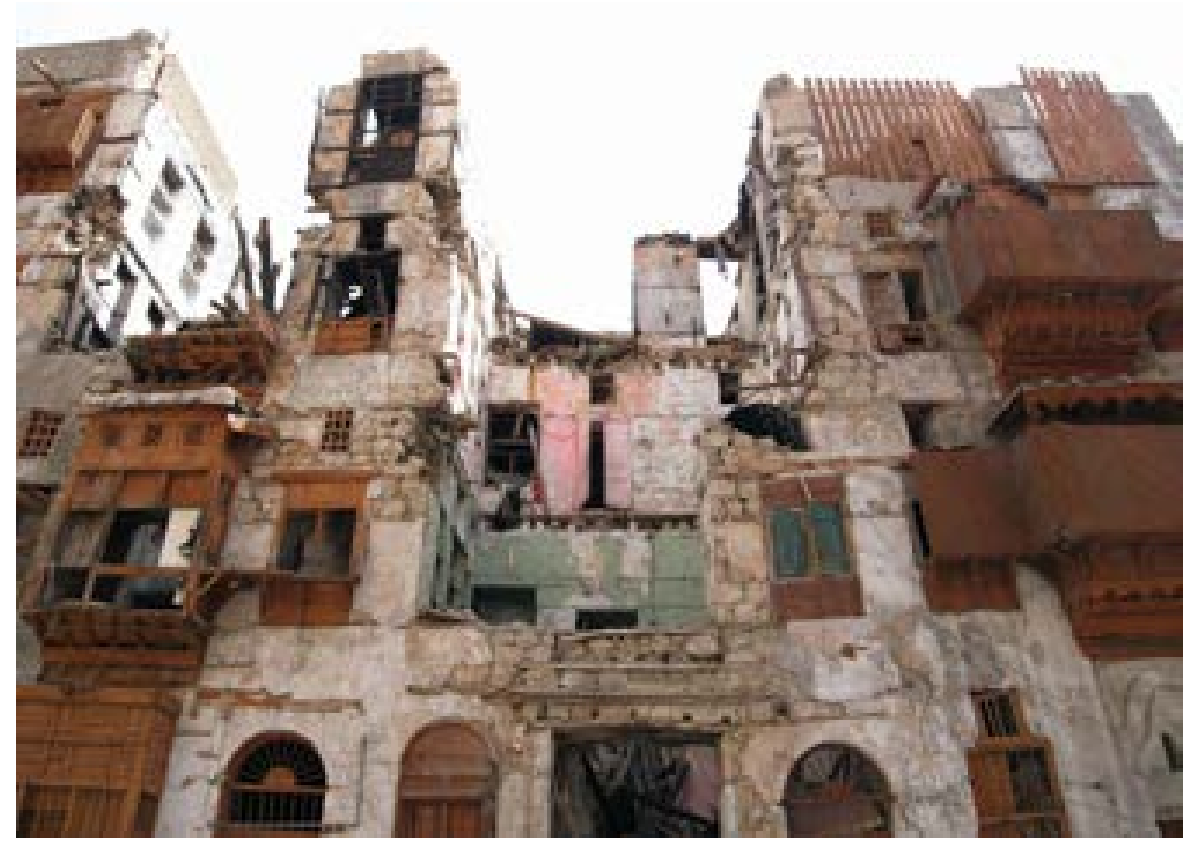




\section{References $\mid$ Referencias $\mid$ Referências}

Assegued, Meskerem; and Sime, Elias. 2002. Zoma Museum. https:// www.zomamuseum.org/zcac-addis-2.html (consulted on 12/7/2021)

Breton, Jean-François. 2015. Les bâtisseurs des deux rives de la mer Rouge. Addis Ababa: Centre français des études éthiopiennes.

Domenig, Gaudenz. 1980. Tektonik im Primitiven Dachbau. Zurich: ETH Zürich.

Ferng, Jennifer. 2015. Elemental Vernacular: Designing Beyond Human Authorship. Architectural Theory Review, vol. 20, 3: 291-295. DOI: 10.1080/13264826.2015.1195479

Friedlander, María-José; and Friedlander, Bob. 2015. Hidden treasures of Ethiopia. London: I.B.Tauris.

Gruber, Petra; and Eissa, Mahmoud. 2014. Old town of Jeddah. Results of the building survey of the Al-Nawar house. Architectura, 1: 1-16.

Last, Jill. 1981. Ethiopians and the Houses they live in. Addis Ababa: Ethiopian Tourism Commission.

Rieger-Jandl, Andrea. 2013. Tradition in transition: reflections on the architecture of Ethiopia; with a special focus on the Afar region. Vienna: IVA-ICRA.

Schefold, Reimar; Nas, Peter; and Domenig, Gaudenz. 2004. Indonesian houses: Tradition and Transformation in Vernacular Architecture. Singapore: Singapore University Press.

Sieghartsleitner, Alexander. 2010. Traditionelle Bauformen im Westen Saudi-Arabiens, Eine Gegenüberstellung der Altbauten von Jeddah und der Lehmbauten des Asir. Diploma Thesis. Vienna: Vienna University of Technology.

Shimizu, Nobuhiro. 2015. An Analysis of the Construction Method of Emperor Yohannes IV's Buildings in Tigray Region, Ethiopia. In Naredra Bondla, James; G. C. Smidt, Wolbert; Furusaki, Yoko; and Bekerie, Ayele (eds.), Cultural Landscapes of Ethiopia: Conference Proceedings. Mekelle: Mekelle University Printing.

Weldekian, Garedew Mengesha. 2015. Transformation of Konso Vernacular Houses. Master Thesis. Addis Ababa: EiABC Addis Ababa University.

\section{Biographies | Biografías | Biografias}

\section{Petra Gruber}

Petra is an architect with a strong interest in inter- and transdisciplinary design. Apart from her professional work as an architect, she holds a $\mathrm{PhD}$ in Biomimetics in Architecture from the Technische Universität Wien, Austria, and has been a Research Fellow at the Centre for Biomimetics at Reading University, UK. She has taught Biomimetics in Energy Systems at the University of Applied Sciences in Villach, Austria, and delivered lectures and workshops at universities across the globe. As Visiting Professor for Architectural Design and Building Science, she set up a master's program in Advanced Architectural Design at the Addis Ababa University in Ethiopia. Her research ranges from projects for the European Space Agency on lunar base design informed by folding principles from nature to arts-based research on the translation of growth principles from nature into proto-architectural spatial solutions. Dr. Gruber has also been based at the Myers School of Arts and the Department of Biology for the Biomimicry Research and Innovation Center BRIC at the University of Akron.

\section{Kingshuk Datta}

Kingshuk Datta, MArch, is a doctoral candidate at the Technische Universität Wien, Austria, researching computational speculations based on Hindu-Buddhist sacral architectures. He holds a Master's in
Advanced Architecture Design from the David Green Studio at Oxford Brookes University, UK. He is a licensed architect in India and has worked and lectured extensively. His research and works are informed by the pluralistic nuances embedded within visual and material cultural practices and the decolonization of architectural production methods. 